$9-1-2012$

\title{
Law Clinics in Taiwan: Can Clinical Legal Education Succeed in This Civil Law Jurisdiction with an Undergraduate Legal Education System?
}

\author{
Serge A. Martinez \\ University of New Mexico - School of Law
}

Follow this and additional works at: https://digitalrepository.unm.edu/law_facultyscholarship

Part of the Law Commons

\section{Recommended Citation}

Serge A. Martinez, Law Clinics in Taiwan: Can Clinical Legal Education Succeed in This Civil Law Jurisdiction with an Undergraduate Legal Education System?, 7 National Taiwan University Law Review 343 (2012).

Available at: https://digitalrepository.unm.edu/law_facultyscholarship/485

This Article is brought to you for free and open access by the UNM School of Law at UNM Digital Repository. It has been accepted for inclusion in Faculty Scholarship by an authorized administrator of UNM Digital Repository. For more information, please contact amywinter@unm.edu, Isloane@salud.unm.edu,sarahrk@unm.edu.

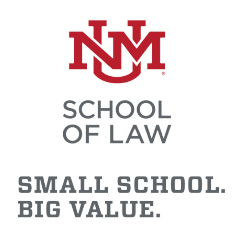

BIG VALUE. 


\title{
Article
}

\section{Law Clinics in Taiwan: Can Clinical Legal Education Succeed in this Civil Law Jurisdiction with an Undergraduate Legal Education System?*}

\author{
Serge A. Martinez ${ }^{* * *}$
}

\begin{abstract}
Law school clinics are an important part of legal education around the world, but there are still many places without clinics, including Taiwan. It is important for Taiwanese legal educators to consider whether and how clinical education might fit into the Taiwanese legal education system. When discussing clinical education, several concerns are commonly raised: are undergraduate students capable of doing and benefitting from clinical work? Is student practice legal? What effect does student practice have on quality of representation? How does a clinic fit with the existing apprenticeship program? Who would teach a clinic? How do clinics fit with the legal academy's view of itself and its purposes? Can Taiwanese law schools afford to operate clinics? Ultimately, none of these concerns presents a serious obstacle to the introduction of clinical education. Taiwanese law schools should introduce clinics to their curriculum to give students the opportunity to enjoy the many benefits of clinical education.
\end{abstract}

" I wish to thank the participants in the ad hoc clinical roundtable group at National Taiwan University organized by Professor Chang-fa Lo for their helpful and insightful comments on the ideas in this paper. I also would like to thank my research assistant Annie Lee. Finally, I would like to thank the Maurice A. Deane School of Law at Hofstra, National Taiwan University College of Law, and the Fulbright Taiwan Foundation for Scholarly Exchange for the research support that made this article possible.

Clinical Professor of Law, Maurice A. Deane School of Law at Hofstra University; Visiting Professor, NTU College of Law for 2011-2013. E-mail: serge.martinez@hofstra.edu. 
Keywords: Clinical Education, Law Clinic, Practical Legal Education, Student Practice, Taiwan, Taiwanese Legal Education 


\section{CONTENTS}

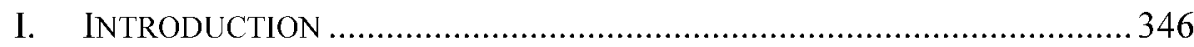

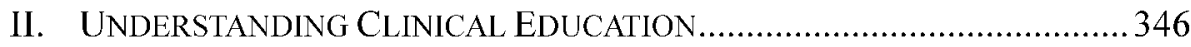

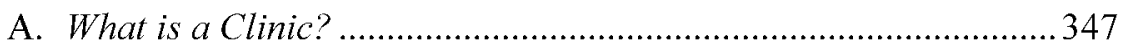

B. The Role of Clinical Education ..............................................349

III. GLOBAL DEVELOPMENT OF CLINICAL LEGAL EDUCATION ....................353

A. Clinical Education in America …………………...........................353

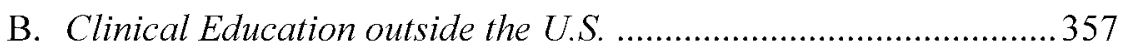

IV. What ABout a CliniC IN A PlaCe LiKE TAIWAN? .............................358

A. Practical Training and the Post-Bar Apprenticeship Program ......360

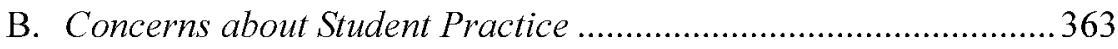

1. Lack of Student Maturity and Ability........................................363

2. Legal Concerns about Student Practice .....................................365

3. Bar Resistance: Stealing Clients and Substandard Practice...368

C. Challenges with Teaching in Clinics ............................................369

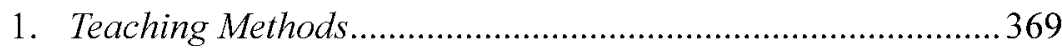

2. Who will Teach Law Clinics? .................................................372

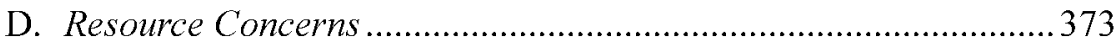

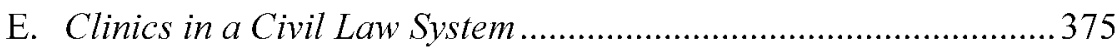

V. Moving Forward in TAIWAN: How CAN Clinics Become A

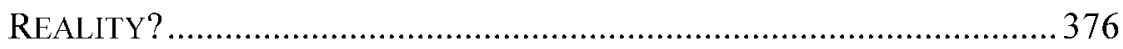

REFERENCES … 


\section{INTRODUCTION}

Every semester, law students around the world are given the opportunity to expand their legal training by representing real clients under the supervision of their law professors. Clinical education has been integrated into law schools throughout the Americas, Africa, Australia, Europe, and Asia. Law faculties worldwide are recognizing the important role that clinical education can play in helping law students transform their knowledge of law into effective, responsible practice of law.

Law students in Taiwan, however, do not have the option of enrolling in a law clinic. While visiting at the National Taiwan University College of Law, I have been working with local lawyers, judges and professors to assess the suitability of a law clinic in Taiwan. I have concluded that it is an appropriate time for Taiwan to introduce clinical education into its legal curriculum. ${ }^{1}$

This article will explore the development and spread of clinical education around the world, and consider whether and how it can work in a country like Taiwan, with its civil code, its tradition of undergraduate legal education and its limited tradition of practical education in law school. Although it is heavily focused on Taiwan, and some aspects of the article are indeed Taiwan-specific, a significant portion of the article can also be useful to other jurisdictions that may be considering implementing or expanding clinical legal education.

In Part II, the article will define and explain law clinics, the benefits of clinical education and the role that clinics can play in a law school curriculum. In Part III, the article will cover the historical development of clinics in the United States and globally. Part IV will examine the current state of legal education in Taiwan and consider whether clinical education can play a meaningful role in such a system. In connection with this inquiry, the article will identify and address several common objections to clinical education before concluding that none of the challenges should delay Taiwan, or any other country with a similar system, from introducing clinical education to its law schools.

\section{UNDERSTANDING CLINICAL EDUCATION}

To understand clinical education, it is important to grasp not only the concept of what clinical education is-what it looks like, how it works from day to day, etc. - but also its place in the curriculum, including the benefits

1. Because of my limited language skills, all of my research was conducted in English. As a result, it is possible that I have missed significant information and insights from others that would have been beneficial to this article. 
to students and legal education generally that can derive from clinics.

\section{A. What is a Clinic?}

Clinical education of law students is a teaching method in which students assume the role of lawyer and are required to deal with legal problems. This method is hardly limited to law-it is common across the spectrum of professional schools, including medicine, nursing, dentistry, engineering, architecture, and others. As it is applied to the study of law, there is no single definition of clinical education. In its broadest sense, it can refer to any sort of experience-based training in law, ${ }^{2}$ including simulations ${ }^{3}$ and externships. ${ }^{4}$ Although the various forms of experiential education can each play important roles in training lawyers, in this article, "clinical legal education" (along with other similar terms such as "law clinics" or "clinics") refers to student representation of real clients under law faculty supervision that is integrated into the law school curriculum.

Obviously every law clinic is different; however, there are some common shared characteristics in how they operate and what they look like. In a typical law clinic, the clinic takes on clients as the attorney of record, ${ }^{5}$ and enrolled students assume the role of lawyers (under careful supervision) and have primary responsibility for solving their clients' legal problems. ${ }^{6}$

2. See, e.g., Stacy Caplow, Clinical Legal Education in Hong Kong: A Time to Move Forward, 36 Hong KONG L.J. 229 (2006); Andreas Bücker \& William A. Woodruff, The Bologna Process and German Legal Education: Developing Professional Competence Through Clinical Experiences, 9 GERMAN L.J. 575 (2008). (Both of these articles, defining clinical education for an audience that may not be familiar with the concept, include simulation courses and externship experiences in that definition.)

3. Simulations are exercises or courses in which students assume the role of lawyer in simulated lawyering situations. These might include interviewing simulated clients, counseling, conducting negotiation exercises, drafting documents, arguing in moot court or other similar exercises. Simulations can be exceptionally valuable teaching tools with respect to lawyering skills and forming a foundation for clinical work. However, they tend to lack the unpredictability and the urgency of representing actual clients, which limits their ability to prepare students for actual practice.

4. Externships place students outside of the law school to work under the supervision of lawyers at, for example, a legal aid office or a prosecutor's office. Externships can help introduce students to the complexities of real clients, cases and courts. They are relatively inexpensive to set up, and can be excellent opportunities for students to have real experiences that they then bring back to the law school for reflection and discussion. However, because most of the experience takes place outside the law school and away from professors, the experience may be uneven, and reflection and feedback can be difficult to give.

5. Structurally, a law school clinic is essentially a small law firm located within the law school. In-house clinics are often separately incorporated entities, usually have discrete space within the law school, and carry their own malpractice insurance. During summer and other breaks, the clients remain the responsibility of the clinic. Typically the professors or summer interns hired expressly for this purpose take charge of representation. In many clinics, including the one that I direct at the Maurice A. Deane School of Law at Hofstra University, students are involved in client selection as well.

6. Supervision varies from clinic to clinic and from student to student. Although it depends on the circumstances of the particular clinic, students in a law clinic can have a tremendous degree of responsibility in the representation of their clients. 
The cases and stories of the clients form the context for the students' educational experience. In their role as lawyers, students engage in all of the tasks that a practicing lawyer might engage in. Depending on the clinic and the client, this includes lawyering tasks such as interviewing clients, counseling clients, engaging in negotiations or other forms of alternative dispute resolution, conducting legal research, planning for representation, drafting litigation or transactional documents, appearing in court, engaging in advocacy in various arenas, legislative advocacy, conducting community education, forming business entities, and other lawyering tasks.

The benefits that flow from working with real clients are the keys to the value of clinical education. Real clients have unique problems, circumstances and personal situations that bring a complexity and unpredictability to clinical education that is difficult to achieve in simulations. ${ }^{7}$ Representing real clients also creates student enthusiasm and motivation as they struggle with the real problems in their clients' lives. This human element gives meaning to student learning and performance in a way that cannot be duplicated in a doctrinal or simulation course. ${ }^{8}$

Although the clients are real clients, the students are not yet lawyers. Intense and constant supervision is necessary to meet the two major responsibilities of clinics: teaching students effectively and providing high-quality client representation. To meet these demands, clinic teachers must take on the dual roles of teacher and expert practitioner. Teaching is supervision intensive-students and professors interact at length in the classroom and in one-on-one meetings to review every aspect of their cases, to painstakingly interrogate every decision by the student-lawyers and protect client interests. This type of highly interactive teaching requires low student-faculty ratios-ideally no more than 8-12 students per professor.

Clinics are quite diverse in their practice areas, depending on local need, student demand, faculty expertise and funding sources. Law clinics focus on such diverse areas as transactional law, alternative dispute resolution, legislative and administrative advocacy, criminal law, capital punishment, international human rights, civil law, disability law, intellectual property, community development, mediation, securities arbitration, child advocacy, environmental law, employment discrimination, elder law, and indigenous rights, among many others. ${ }^{9}$

7. As one expert in another field -piloting a commercial airplane - puts it: "You can get everything in a simulation except for the feeling, the real feeling, of the last 200 feet of landing." Pauline W. Chen, Practicing on Patients, Real and Otherwise, N.Y. TIMES, Feb. 2, 2010, at D6. Simulations are wonderful pedagogical tools, but they obviously have their limitations.

8. See Stefan H. Krieger \& Serge Martinez, A Tale of Election Day 2008: Teaching Storytelling Through Repeated Experiences, 16 LEGAL WRITING 117, 154-55 (2010).

9. It is an open question whether there are any areas of law that would not be suitable for clinical education. Although no doubt every individual has their own ideas about what would or would not be 
Of course, this description of clinics is necessarily a broad generalization. With thousands of clinics worldwide, there is no such thing as a "typical" clinic, and clinics around the world reflect local conditions. The unifying characteristics are, ideally, the presence of real clients, student representation of clients, and intense supervision by a faculty member who is an expert practitioner in the area of law.

\section{B. The Role of Clinical Education}

Understanding clinics also requires an understanding of the role clinics can play in legal education. Clinical education has many benefits: helping students apply doctrinal learning to practice, teaching essential lawyering skills, training students to learn from their own experiences, exposing students to questions of ethics and professional responsibility, and providing legal services to underserved communities.

Notwithstanding all of these qualities, however, clinical education is often thought of narrowly as education in skills. There is no doubt that clinics are an unparalleled opportunity for students to get hands-on training in a wide variety of lawyering skills that are applicable across a broad spectrum of practice settings, including across cultures and jurisdictions. ${ }^{10}$ Students get experience with important skills such as interviewing, counseling, negotiation, investigation of facts, drafting, advocacy, and legal analysis. They learn the importance of cultural awareness, interpersonal relationships, creativity, and flexibility in representation of clients.

Given the frequency and forcefulness with which this benefit of clinics has been claimed, it is not surprising that clinics are susceptible to dismissal as narrowly focusing on skills training and teaching nothing more than technique and performance skills. There is a common misunderstanding that, while doctrinal teaching is focused on "thinking like a lawyer," clinics are purely focused on "doing like a lawyer." The reality is that clinical education transcends simple skills training. In fact, a primary educational benefit of law clinics stems from their ability to enhance students' doctrinal learning by teaching them how to apply that learning to real clients.

Imagine, for example, a client who has suffered damage to her home due to the actions of another person. The student who is familiar with the law as it relates to this type of tort may be able to tell the client all of the

suitable, the broad range of clinical offerings suggests that no matter what the area, there is probably someone who is willing and able to create a clinic in that area. However, I believe that some types of practice that require significant amounts of technical knowledge and special skills would not be well-suited to introducing law students to the practice of law.

10. Although of course doctrinal differences between jurisdictions can be vast, core lawyering skills such as communication with clients, providing good advice, and providing ethical representation look very similar in any jurisdiction. 
elements necessary for a successful lawsuit. The student who has learned the skill of client interviewing might uncover a rich factual background and get a clear understanding of the client's goals and priorities. Either of these students alone, however, is unlikely to be of great value to the client in resolving the client's problem. An effective lawyer must combine client communication skills with doctrinal knowledge to understand the client's options under the law, understand how each option affects the client's individual situation and preferences, and put the client in a position to make the best possible decision about what to do. The law clinic is the laboratory where students learn to combine the various elements of effective lawyering in a controlled, supervised setting.

The clinical method allows a nuanced integration of practical elements with the doctrinal foundation that students receive early in their legal training. As with the example of the client above, a thoughtful and intentional application of effective lawyering skills to a deep doctrinal and analytical understanding of the relevant law is needed in virtually every aspect of effective client representation. Teaching students to seamlessly integrate reasoning and performance is the foundation to developing lawyering expertise, ${ }^{11}$ and it is a task that clinics are well-suited to address.

A common metaphor for the work of clinics is a bridge connecting theoretical and practical elements of lawyering. Both are essential to effective client representation: without the opportunity for practice, doctrinal learning remains abstract and difficult to use. Without a solid doctrinal foundation to provide context, skills training can become purely performance-based. The clinical experience requires students to apply legal analytical and reasoning abilities to a client's problems as well as use effective lawyering skills that can translate analytical reasoning into a practical solution for the client's problem. This type of experience can help students begin to develop real expertise in lawyering.

Therefore, clinics can best be understood not as separate from but rather as an extension of doctrinal learning ${ }^{12}$ - as the chance to integrate doctrine

11. Stefan H. Krieger \& Serge A. Martinez, Performance Isn't Everything: The Importance of Conceptual Competence in Outcome Assessment of Experiential Learning, 19 CLINICAL L. REV. (forthcoming 2012).

12. One argument for clinics is that by requiring students to apply doctrine to real situations they actually develop a better understanding of the doctrine. George S. Grossman, Clinical Legal Education: History and Diagnosis, 26 J. LegAL EduC. 162, 171 (1974). See also Barbara J. Busharis \& Suzanne E. Rowe, The Gordian Knot: Uniting Skills and Substance in Employment Discrimination and Federal Taxation Courses, 33 J. MARSHALL L. REV. 303, 341 (2000) (suggesting that practical education in the area of employment discrimination increases student understanding of doctrine). I have had a similar experience when guest teaching in a Family Law class about surrogacy contracts. See Andrew Schepard \& J. Herbie DiFonzo, Hofstra's Family Law with Skills Course: Implementing FLER (The Family Law Education Reform Project), 49 FAM. CT. REV. 685 (2011) (describing this course). When students are required to draft contracts that meet exacting legal requirements, they understand not only more about the art and skill of drafting, but they internalize the doctrine as well. 
into a practical learning context that requires not only a deep understanding of the doctrine, but also mastering practical skills, understanding contextual elements, ethics, and professional responsibility. ${ }^{13}$

Clinics also prepare students for practice by teaching them to reflect on and learn from their own experiences. Because the core educational element of clinical education is the student's experience in the context of client representation, the most sophisticated clinical education is focused on helping students examine and reflect on their own practice experiences to determine what lessons they can learn from them. ${ }^{14}$ This focus can help address one of the limitations inherent in most formal education-three years of law school is not nearly enough time to teach students all the law that they will need during the decades that they will be practicing law. Teaching students to learn from experience can be the difference between those decades being a "blundering, inefficient, hit-or-miss learning experience in the school of hard knocks" or "a reflective, organized, systematic learning experience-if the law schools undertake as a part of their curricula to teach students effective techniques of learning from experience." 15 The difference resulting from the ability to learn from experience can be that of progressing steadily for five years after leaving law school, or "essentially repeating the initial year of practice five times."

Another role of clinics within the curriculum is teaching professional responsibility and developing a professional identity in young lawyers. Although the values of the law pervade the curriculum, those concepts can be abstract and difficult to grasp when they are purely theoretical. Except in law clinics, students have very few opportunities to engage seriously with important concepts and values such as promoting justice, fairness, morality, the role of the profession in society, and the ethical challenges that regularly present themselves to lawyers in practice.

Because most clinic clients tend to come from low-income communities, ${ }^{17}$ clinic students often have their first contact with systemic

This can only be taken so far, however-no clinical experience can cover every aspect of doctrine. As discussed above, in fact, one of the benefits of clinics is their ability to transeend the particular area of practice.

13. Of course, even law students who take clinical courses will not be fully-formed expert practitioners after just a few months-or even a whole academic year-of a clinic course. Rather, they have been given a good introduction to connecting legal doctrine and expert practice, and had some training in how they can learn from their own future experiences.

14. Robert Dinerstein, Report of the Committee on the Future of the In-House Clinic, 42 J. LEGAL EDuc. 508, 511 (1992); Margaret Martin Barry et al., Clinical Education for this Millennium: The Third Wave, 7 CLINICAL L. REV. 1, 32 (2000).

15. Anthony G. Amsterdam, Clinical Legal Education-A 21st century Perspective, 34 J. LEGAL EDUC. 612, 617 (1984).

16. William P. Quigley, Introduction to Clinical Teaching for the New Clinical Law Professor: A View from the First Floor, 28 AKRON L. REv. 463, 474-75 (1995).

17. This is due to historic and practical reasons. Clinics have always had a strong focus on social 
inequities, get their first view of the different ways that laws affect poor and marginalized communities, and gain their first understanding of the difference that access to representation can make. By exposing students to these issues during law school, the time that young lawyers are developing their professional identities, ${ }^{18}$ clinics can play an important role in shaping those identities. This experience can, ideally, result in an increased commitment to the provision of legal services to those in need.

Representing clients with unmet needs can also have a significant impact outside of the law school by providing access to representation for individuals and communities that otherwise might not be able to find lawyers. Indeed, in some parts of the world, law school clinics are the primary or one of the primary sources of legal services for individuals or communities with limited resources. Law clinics have historically played an important role in many places in helping increase access to justice, law reform, support of the rule of law, access to the profession of the law and other important effects. ${ }^{19}$ Even in prosperous nations with robust traditions of rule of law, there are invariably unmet needs that clinics can help reduce.

The benefits of law clinics are many. When they are fully understood, it is clear that law clinics can play a significant role in the legal curriculum by helping students connect doctrine and practice, learn important lawyering skills, and understand professional responsibility while providing assistance to individuals and communities with unmet legal needs.

To get a better understanding of clinical education, it can be helpful to understand the roots and history of clinics. The next section explores where clinics came from and how they developed from the ancient tradition of apprenticeship to the modern, cutting-edge educational experiences that can be found today.

justice, and many, if not most, clinics have income guidelines restricting their services to clients with limited resources. In addition, despite clinics' reputation for top-notch legal work, the slow-motion and educational nature of clinics tends to discourage clients who can afford experienced private counsel.

18. Leah Wortham, Aiding Clinical Education Abroad: What Can Be Gained and the Learning Curve on How to Do So Effectively, 12 CLINICAL L. REv. 615, 633 (2006).

19. There is some ongoing debate concerning the relative importance of pedagogy and public interest in clinical work. Access to justice and other public interest efforts are, of course, incredibly important and should be a significant piece of lawyers' work. Clinics have historically had a strong focus on social justice issues, and that is one of the greatest sources of their popularity, particularly in legal systems with less robust rule-of-law systems. However, some argue that this role should not be the primary focus of a clinic. For an insightful discussion of this point, see Richard J. Wilson, Training for Justice: the Global Reach of Clinical Education, 22 PENN. ST. INT'L L. REV. 421, 430 (2004) (arguing that "a conception of the primary mission of clinical legal education as that of service to the poor rather than training of students risks failure in both"). 


\section{GLOBAL DEVELOPMENT OF CLINICAL LEGAL EDUCATION}

Clinical education is not just an American creation. ${ }^{20}$ Learning to be a lawyer through supervised practice is a very old idea-for generations, lawyers around the world learned to practice through apprenticeships with practicing attorneys. The roots of the modern global clinical movement, however, are firmly rooted in the proliferation and permanence of clinics that began in the U.S. around the 1960s. ${ }^{21}$

\section{A. Clinical Education in America}

As is true of most jurisdictions, America originally relied predominantly on an apprenticeship model to train its lawyers. That began to change with the development of the "case method" of teaching in the late $1800 \mathrm{~s}$, which has become closely identified with Christopher Columbus Langdell, the dean of the Harvard Law School from 1870 to 1895 . Under this method, legal training was based on reading judicial decisions with the goal of extracting and analyzing legal principles and reasoning. The goal was to teach students how to "think like a lawyer." This model soon swept away other models of lawyer training to become essentially the only acceptable means of preparing lawyers. As the case-based method became more established, law schools gained academic legitimacy and found a place within the university-they were no longer considered mere "trade schools." As they increased in academic respectability, law schools moved farther away from practical education. $^{22}$

However, the case-based method was a source of criticism almost from the very beginning ${ }^{23}$ - not necessarily criticism of the method itself, ${ }^{24}$ but rather of the exclusive reliance on this method for teaching young lawyers. ${ }^{25}$

20. They seem to have developed more or less independently in several places. In his 1917 article touting clinical education, Professor William Rowe describes a program already in existence "for years" in Copenhagen (William V. Rowe, Legal Clinics and Better Trained Lawyers-A Necessity, 11 ILLINOIS L. REV. 591 (1917)). Professor Richard Wilson describes the development of clinics in Chile around 1970 (See Richard Wilson, Three Law School Clinics in Chile, 1970-2000: Innovation, Resistance and Conformity in the Global South, 8 CLINICAL L. REV. 515 (2001-2)).

21. The American experience with clinical education has been discussed in great detail elsewhere. To name just a few sources, for a more complete history, see e.g., Barry et al., supra note 14, at 5-21 (detailing the rise of clinical education in several stages); Bücker \& Woodruff, supra note 2, at 578-88 (providing a comprehensive review of the development of clinical education in America in discussing how clinical education might be appropriate in German legal education); ROBERT STEVENS, LAW SCHOOL: LEGAL EDUCATION IN AMERICA FROM THE 1850 S TO THE 1980 s (1987).

22. Grossman, supra note 12, at 164; Bücker \& Woodruff, supra note 2 , at 585 .

23. Grossman, supra note 12, at 164.

24. There is much to admire in the case method, including the efficiency of learning, cost effectiveness due to large possible class sizes, the way it can teach students to effectively make sense of the dynamic, ever-changing law, and its ability to adapt to a quickly-changing system.

25. One prominent critic suggested that the case method could be mastered in about six months, 
The preponderance of the case-based method left almost no room in the law school curriculum for practical training. ${ }^{26}$ As a result, critics doubted the ability of the law schools to prepare lawyers for practice ${ }^{27}$ and called for more focus on the practical side of legal education as well as a better connection between the law schools and the actual practice of law. ${ }^{28}$ One famous critique argued that "students trained under the Langdell system are like future horticulturalists confining their studies to cut flowers, like architects who study pictures of buildings and nothing else. They resemble prospective dog breeders who never see anything but stuffed dogs. ${ }^{9,29}$

Even as the case-based method was establishing its dominance, there were efforts to supplement its narrow focus with practical legal education. Throughout the late $1800 \mathrm{~s}$ and early $1900 \mathrm{~s}$, there were several student-led initiatives to start student-staffed legal aid offices, with the goal of supplementing doctrinal training. ${ }^{30}$ But the growth of clinical education faced several challenges. Resource-intensive clinical work was not a priority for law schools with persistent resource shortages. At the same time, law schools looking for academic credibility and professional legitimacy were actively trying to distance themselves from the old apprenticeship model ${ }^{31}$ and to rid themselves of the label of "trade schools."

The criticism of the case-based method continued, however, and at mid-century the issue of practical training was an important one in American legal education. ${ }^{32}$ However, even though there was an ongoing national conversation about practical education and clinical education, by 1959 there

after which time boredom would set in. Grossman, supra note 12, at 166, quoting JEROME FRANK, COURTS ON TRIAL 237. The 2007 so-called Carnegie Report similarly criticizes the academy for its continued over-reliance on this method of teaching as counter-productive for student learning. William M. Sullivan ET al., EduCATing LaWyers: PreParation For the Profession of LaW 77 (2007).

26. Dean Langdell was dismissive of practical training for students and even in law professors. He is quoted as saying "What qualifies a person...to teach law is not experience in the work of a lawyer's office, not experience in dealing with law, not experience in the trial or argument of cause - not experience, in short, in using law, but experience in learning law." J. W. HURST, GROWTH OF AMERICAN LAW 263 (quoted in Grossman, supra note 12, at 162).

27. It should be noted that in American legal training, there is no requirement for any practical education - as soon as students pass the bar exam (which owes much to the case method of education) they are able to begin practice, with or without supervision or practical training.

28. Karl Llewellyn et al., The Place of Skills in Legal Education, 45 CoLuM. L. REV. 345, 353 (1945). ("the case method is failing to produce reliable professional competence" in many graduates). Professor Rowe in 1917 argued that law schools needed more clinical education and that they were lagging behind other disciplines such as medicine and engineering. Rowe, supra note 20, at 591-96.

29. Jerome Frank, Why not a Clinical Law School?, 81 U.PA. L. REV. 907,908 (1933).

30. As has been the case throughout the history of clinical education, a companion to this educational goal was the goal of providing legal services to needy clients.

31. This was probably not altogether a bad thing. The apprenticeship model is described as being "in disrepute" in 1974 due to its uneven experience and potential for exploitation. Grossman, supra note 12 , at 164 .

32. As early as 1951 , clinics were described as "one of the current controversies in legal education" Quintin Johnstone, Law School Clinics, 3 J. LEGAL EDUC. 535, 535 (1951). 
were no more than 35 schools offering "clinical" opportunities for students. ${ }^{33}$ Only five of these were serious enough about clinical education to give teaching credit to professors for teaching clinics. Around the country, "the level of faculty involvement and supervision varied greatly, and clinical experiences existed on the fringes of the law school curriculum." 34 Although it was certainly present to a small degree, clinical education was a sideshow in American legal education for the greater part of the $20^{\text {th }}$ century. ${ }^{35}$

However by the 1960 s, the situation had begun to change. Law student and faculty dissatisfaction with legal education was growing, ${ }^{36}$ and there were demands for relevance from law schools during a time of particularly notable social change in America. ${ }^{37}$ Criticism of legal education persisted in influential quarters. $^{38}$

The most significant factor, however, was probably the availability of funding to expand clinical education. Beginning in 1959, law schools had access to private and then government funding to help establish law school clinics. ${ }^{39}$ This infusion of money had the intended effect: within a very short time, clinics had spread to a majority of US law schools. In 1971, 85 law schools had clinics of some type. By 1997, when the last of the funding was discontinued, at least 147 law schools had law clinics. ${ }^{40}$ Clinics had completed a metamorphosis from novelty program to an accepted-and expected-element at any law school trying to attract top students.

An important consequence of the explosive growth of clinics was the creation of a critical mass of clinical professors. Where before there were only a few lonely outliers doing clinical work, suddenly there was a large cohort of new clinical professors engaged in teaching and in serious thinking about clinical education. Under these conditions, clinicians developed a body of scholarship about issues such as teaching in a clinical setting, improving

33. Barry et al., supra note 14 , at 10.

34. Id. at 11 .

35. At the same time as clinical education was gaining some currency, other types of practical education such as moot court, legal writing programs were being experimented with. There is some suggestion that this diverse array of practical education may have actually hindered the progress of law clinics by diverting attention and resources from the clinical movement. Barry et al., supra note 14, at 32.

36. Barry et al., supra note 14, at 11.

37. In the memorable words of Professor Dean Hill Rivkin, "the social fervor penetrated law schools quite passionately" Symposium, Clinical Legal Education: Reflections on the Past Fifteen Years and Aspirations for the Future, 36 CATH. U. L. REV. 337, 340 (1987).

38. Caplow, supra note 2, at 232. For example, in 1973 Warren Burger, at that time the Chief Justice of the United States argued the need for more skills training. (W. Burger, The Special Skills of Advocacy: Are Specialized Training and Certification of Advocates Essential to our System of Justice?, 42 FORDHAM L. REV. 227 (1973); Barry et al., supra note 14, at 32.

39. Initially, the money came from the Ford Foundation. Soon afterward, the US Department of Education also made funding available to law schools that were starting law clinics. See Barry et al., supra note 14 , at 18-20.

40. Id. at 19 . 
and implementing the supervisory process, and experiential learning theory. A common vocabulary developed, and with it an articulation of the goals of clinical education. In this atmosphere of experimentation, study and sharing, a particular clinical methodology developed. ${ }^{41}$ In short order, clinical education began to move from the fringes of legal education to "an area of legitimate scholarly inquiry. ${ }^{, 42}$ Today, virtually every American law school has clinicians on the faculty. Multiple journals are devoted to clinical education and clinical scholarship regularly appears in other journals. With the blossoming of clinical scholarship, "clinical legal education gained a more permanent place in law schools., ${ }^{, 43}$

Once they were given the chance to flourish, clinics gained a solid place in the mainstream of American legal education. Given the long American tradition of marginalization of - or even outright hostility to - practical education, it might have been expected that without sustained outside funding, clinics would disappear. Somewhat surprisingly, however, that did not happen. Although the foundation and government money was undoubtedly instrumental in the initial establishment of many clinics, after the funding stopped, the number of clinical teachers increased, along with job security and status for clinical faculty. ${ }^{44}$ Clinical education found itself on a more solid foundation in 1996, when the American Bar Association changed the standards for accreditation of law schools to require law schools to give students the opportunity for clinical "or other real-life practice experiences. $\$ 45$

Clinics had proven their value. Law schools and their students had gained an appreciation for the value of clinical education within the curriculum. By 1999, at least 183 US law schools had clinical programs. ${ }^{46}$ In the fall 2010 semester, there were over 1000 clinics offered. ${ }^{47}$

The American experience has demonstrated that clinical education has a place in law school. Its enduring popularity with students, the academy, and the practicing bar is a testament to the benefits it can provide. Although it would be a mistake to conclude that clinical education no longer faces

41. $I d$. at 32 .

42. Bücker \& Woodruff, supra note 2, at 575 .

43. Barry et al., supra note 14 , at 32 .

44. Id. at 32 .

45. ABA Standards for Approval of Law Schools 2012-2013 $\S 302(b)(1)$ (2012). The ABA specifically notes, however, that "[a] law school need not offer these experiences to every student nor must a law school accommodate every student requesting enrollment in any particular live-client or other real-life practice experience.") Id. at Interpretation 302-5. (As used here, "live-client" means an experiential course involving representation of real clients, as opposed to a simulation course.)

46. Barry et al., supra note 14, at 32.

47. David A. Santacroce \& Robert R. Kuehn, Center for the Study of Applied Legal Education, The 2010-11 Survey of Applied Legal Education (May 16, 2012),

http://www.csale.org/files/CSALE.Report.on.2010-11.Survey.5.16.12.Revised.pdf. 
challenges, clinics are a permanent feature of American law schools.

From its earliest roots in American legal education, the clinical movement can be understood to be an effort to diversify the education of law students, rather than a rejection of doctrinal training or an effort to return to the apprenticeship roots of legal training. It has existed more or less peacefully alongside more traditional types of legal education in an arrangement that seems likely to persist for some time.

\section{B. Clinical Education outside the U.S.}

While clinics were establishing themselves in American legal education, the clinical boom quickly went from an essentially American phenomenon ${ }^{48}$ to a global movement. Clinics are thriving in South America, Canada, the U.K., Australia, and Eastern Europe. There are over 160 clinics in Russia. ${ }^{49}$ In the Asian region, clinics have been created in such places as India, Malaysia, Cambodia, Thailand, the Philippines, Japan, and China. In China, where the first clinic was started in 2000, more than 60 schools have joined the Committee of Chinese Clinical Legal Educators. ${ }^{50}$ Clinics are even starting to appear in Western Europe, where they have long faced resistance. ${ }^{51}$ Regional and global organizations provide support and opportunities to exchange ideas and develop scholarship independent of US involvement. Clinics have become a worldwide phenomenon.

The growth has come for a variety of reasons and in a variety of ways. Some of it has been the result of funding expressly aimed at legal reform and/or increasing access to justice in countries going through transitional periods. ${ }^{52}$ In places like Japan ${ }^{53}$ and Western Europe, ${ }^{54}$ the introduction of clinics has coincided with comprehensive efforts to reform legal education to

48. There is, of course, the notable exception of Chile, as mentioned above. Wilson, supra note 20 , at 515 .

49. Richard Wilson, Western Europe: Last Holdout in the Worldwide Acceptance of Clinical Legal Education, 10 GERMAN L.J. 823, 825 (2009).

50. Note, Adopting and Adapting: Clinical Legal Education and Access to Justice in China, 120 HARV. L. REV. 2134, 2139 (2007).

51. Wilson, supra note 49 , at 825 .

52. For a comprehensive history, see Wortham, supra note 18, at 615; Peggy Maisel, The Roles of US Law Faculty in Developing Countries: Striving for Effective Cross-Cultural Collaboration, 14 CLINICAL L. REV. 465 (2008).

53. Clinics became more common in Japan after the 2004 reforms that were intended in part to create a bridge between "theoretical education and practical education" to help students get the knowledge "necessary for solving actual legal problems." Recommendations of the Justice System Reform Council - For a Justice System to Support Japan in the 27st Century, Chapter III, Part 2.2.(1)a-b (June 12, 2001), http://www.kantei.go.jp/foreign/judiciary/2001/0612report.html.

54. A goal of the so-called Bologna Process currently underway in Western Europe is to "provide students not just with technical knowledge of the law but also with competences and skills required for a successful legal career and active participation in economy and society." Bücker \& Woodruff, supra note 2 , at 577-78. 
make it more relevant to the needs of practice. Obviously, clinical education can meet a variety of needs and goals of diverse legal education systems.

As clinical education has gone global, it has also shown its ability to adapt. The internationalization of clinics is not simply a case of transplanting the American model wholesale into a new location-local needs, norms, and limitations must be considered. ${ }^{55}$ Rather than simply adopting models originating elsewhere, local clinicians examine the American experience and combine the American and other models with local issues. ${ }^{56}$ The global proliferation and endurance of clinical education makes it clear that clinical education can be adapted to virtually any legal education system, and that law faculties and students worldwide believe in the benefits that flow from clinical education.

\section{What about a Clinic in a Place Like Taiwan?}

Although a recent article claims that Western Europe is the "last holdout" in global clinical education, ${ }^{57}$ there are still places, like Taiwan, ${ }^{58}$ where clinical education has not been implemented. Of course, simply being an outlier does not imply the need to rush to incorporate clinical education into its legal system - "everybody else is doing it" is rarely a sound basis for doing anything. It is important to understand whether clinical education would fit and would be sustainable before attempting to introduce it. ${ }^{59}$

55. "Clinical teaching programs reflect specific goals about educating students for practice. As such, these programs are very much a product and reflection of their legal cultures." Philip M. Genty, Overcoming Cultural Blindness in International Clinical Collaboration: The Divide between Civil and Common Law Cultures and Its Implications for Clinical Education, 15 CLINICAL L. REV. 131 (2008).

56. Maisel, supra note 52, at 480-81.

57. Wilson, supra note 49 , at 825 .

58. There are, however, a few opportunities for experiential education. Many students in undergraduate law schools participate in courses called Legal Aid Society. In the long tradition of these courses, students provide limited legal assistance to individuals who cannot afford private counsel. The students open their office to clients at a regular time, and offer to help anyone who walks through the door. The students work in small groups to interview clients, assess their legal problems, and provide legal opinions and legal advice. The relationship is limited, however, because students may not draft documents or advocate on behalf of these clients. Supervision and training of new students are largely the responsibility of experienced students. Usually a full-time faculty member is present to observe the students, correct legal inaccuracies, and help students answer particularly challenging questions. These courses have been a significant source of legal assistance to low-income individuals for many years, and they have been valuable tools to introduce countless students to the importance of and need for representation of low-income clients. However, the limited nature of the legal assistance provided to clients and the nature of supervision and training for students mean that these courses provide a very different learning experience for students than a clinical experience would provide. Other types of experiential learning experiences include judicial internships, externship opportunities, moot court competitions and simulation courses. See Chih-Hsiung Chen, The Role of Practice in Legal Education: National Report for Taiwan, paper delivered at the 18th International Congress on Comparative Law (Jan. 12, 2012), http://ssrn.com/abstract=1984374.

59. Clinics are not necessarily a good fit in every legal education system. See, e.g., Rodney Uphoff, Why In-House Live Client Clinics Wont Work in Romania: Confessions of a Clinician 
There is every reason, however, to think that introducing clinical legal education in Taiwan would be beneficial. The ability of clinics to prepare students for practice, to connect doctrine and practice, to learn valuable lawyering skills that transeend borders and jurisdictions, and to understand professional responsibility are all needed by students in Taiwan, as they are in law schools around the world.

Clinics may be especially important in light of some of the criticism leveled at Taiwanese legal education and lawyers. The legal education system has been accused of failing to respond to the globalization of law practice $^{60}$ and, consequently, hindering the ability of young Taiwanese lawyers to compete in a global age in which they face increasing competition from lawyers around the world. One effect of this is the tendency of Taiwanese businesses to rely on foreign lawyers for sophisticated legal needs. ${ }^{61}$

Clinical legal education would complement this globalizing trend by increasing the preparedness for practice and ability to adapt of Taiwanese lawyers, as well as giving them training in skills and competencies that will help them thrive in the current market. In addition to facing competition inside Taiwan, in an age of increasingly global law practice, lawyers trained in Taiwan may be working anywhere in the world, within a variety of legal systems. Changes to the way that law is practiced by Taiwanese lawyers require changes to the way that law is taught in Taiwan. Clinical education can help Taiwanese lawyers compete with lawyers from around the world - many of the benefits of clinical education can transcend national borders and jurisdictional boundaries in preparing students for global practice.

Of course, clinics can also benefit preparation of lawyers for practice in a domestic setting. As I have spoken with Taiwanese lawyers and judges, I have frequently heard complaints along the lines of "new lawyers know everything, but they don't know anything." That is-they have a formidable knowledge of legal codes and are skilled in legal analysis, but they do not have the slightest idea about how to be lawyers, and often they do not even realize that there is a difference-a significant challenge for a beginning lawyer. Clinical education is aimed at addressing this very issue, and could significantly enhance the quality and preparation for the practice of young lawyers in Taiwan.

Finally, another critique of Taiwanese legal education has addressed perceptions of a systemic failure to encourage independent thought and

60 Chang-fa Lo, Driving an Ox Cart to Catch Up with the Space Shuttle: The Need for and Prospects of Legal Education Reform in Taiwan, 24 WIS. INT'L L.J. 41, 43 (2006).

61. Id. at 43-44. 
promote the values of fairness, justice and helping disadvantaged communities. ${ }^{62}$ Clinical education would address this criticism by putting students into situations that develop these important lawyering values. By giving students the chance to work with clients who have unmet legal needs, clinics can help them understand professional responsibility and encourage them to pursue the goals of "promoting social justice, protecting human rights, and contributing to democratic government and the rule of law ${ }^{\$ 63}$ that are expected of all attorneys in Taiwan.

So why, given the many attractions of clinical education, it has not been tried in Taiwan? One possibility might be a simple lack of familiarity-although most Taiwanese law professors have had overseas training, there has been a long tradition of going to Japan and Germany, ${ }^{64}$ two places that have only recently begun to incorporate clinical education into their law schools.

In addition, however, among those Taiwanese professors, judges, lawyers and law students who are familiar with clinics, I have also heard several different concerns about the sustainability of clinics in Taiwan. Most of these are common around the world, relating to student ability and maturity, local rules about non-lawyer practice of law, funding concerns and the existence of an established apprenticeship system that has managed to produce Taiwan's many fine lawyers. Clinics are also often perceived as posing challenges to the traditional faculty and inciting controversy about the goals of law school. In this section, I will address the most common and significant of these concerns, including general as well as Taiwan-specific concerns.

\section{A. Practical Training and the Post-Bar Apprenticeship Program}

The historical approach to practical training in many places, including Taiwan, has been to require a post-bar apprenticeship program before lawyers are licensed to practice. ${ }^{65}$ By tradition, practical legal training has been entirely out of the hands of law schools, although it need not be. ${ }^{66}$ And perhaps should not be. Although apprenticeships have historically been

62. $I d$. at 43. This criticism is common vis-à-vis the Taiwanese educational system in general. Act).

63. Lu_Shih Fa [Attorney Regulation Act] \& 1 (2010) (Taiwan). (hereinafter Attorney Regulation

64. Of course, many Taiwanese law professors studied in the United States, where they surely had some contact with the clinical education going on there.

65. This requirement applies to lawyers engaged in client practice. Judges and prosecutors are required to complete separate training programs.

66. Although the law establishes the apprenticeship program, it does not limit the ability of law schools to engage in practical training. See Lu_shih Chihch'ien Hsünlien Kuitsê [Regulations Governing Pre-Service Training for Attorneys]. (hereinafter Regulations Governing Pre-Service Training for Attorneys). 
popular around the world, they are losing popularity. Even in places with enduring traditions of keeping practical training out of law school, such as Japan and Western Europe, law schools have been given-or have taken upon themselves-more responsibility in the practical training of lawyers. ${ }^{67}$

Currently, the practical training requirement for Taiwanese lawyers is a six-month, two-part "training" period. ${ }^{68}$ In part one, the new lawyer is required to attend a one-month series of lectures-five days a week, eight hours a day - surveying many areas of law. Then, the lawyer is required to spend five months working under the mentorship of an experienced attorney. Only then will the lawyer be licensed to practice.

The intent of the apprenticeship is similar to the objective of clinical education - to bridge the gap between doctrinal study and representation of clients. In theory, an intensive practical experience following formal academic education is unassailable. There is no doubt that "a well-designed, carefully supervised apprenticeship program could play the role that clinical legal education plays in the U.S.," ${ }^{69}$ where there is no apprenticeship requirement. The problem, however, is in the execution: Taiwan's current apprenticeship program is not well-designed for teaching young lawyers how to connect theory and practice, and has no way to ensure careful supervision of their learning.

Rather than a predictably valuable opportunity for a gradual introduction to the profession at the guidance of an expert, the apprenticeship has become an unpredictable and uneven experience, lacking uniformity from lawyer to lawyer. There are no set criteria for training and no quality control for the trainers, and only limited methods in place to regulate the apprenticeship program. ${ }^{70}$ The experience is as varied as there are members of the bar who are training new lawyers. And the problem is only going to get worse.

Recently, Taiwan has seen an increase in law schools, ${ }^{71}$ law students, and the number of people passing the bar examination. ${ }^{72}$ The result is a much larger number of young lawyers who need to be trained than ever

67. Peter Joy et al., Building Clinical Legal Education Programs in a Country without a Tradition of Graduate Professional Legal Education: Japan, Educational Reform as a Case Study, 13 CLINICAL L. REV. 417 (2006); Wilson, supra note 49, at 823.

68. Regulations Governing Pre-Service Training for Attorneys $\$ 5$.

69. Wilson, supra note 49 , at 832.

70. Mentors must have at least 5 years of practice, Regulations Governing Pre-Service Training for Attorneys $\$ 9$, and interns are permitted to report "improper" guidance. $I d$. $\$ 11$. While these regulations provide a baseline element of quality control, they do not offer any guidance for the training program.

71. From 1995 to 2004 the number of law programs effectively tripled, from 33 to 94 . Lo, supra note 60 , at 50 .

72. In 2011, 964 lawyers passed the bar exam. While this may seem low to lawyers from some other jurisdictions, it is significantly up from just $\mathbf{4 0 0}$ as recently as 2004 , and much higher than the historically low passage numbers. 
before. These numbers are putting increasing pressure on the existing practicing $\mathrm{bar}^{73}$ to meet the mounting demand for training. The combination of a small number of suitable mentors and a dramatic increase in the number of new attorneys looking for internships may simply be too much for the small bar to handle, however well-intentioned it may be ${ }^{74}$ Busy practitioners are simply less able to help students integrate theory, practice and professional identity in a meaningful way. ${ }^{75}$ At the same time, there is no incentive for the supervisor to invest resources in training a young lawyer who may soon be competing for clients in a rapidly-filling marketplace. The structure of the apprenticeship requirement creates a situation where many young lawyers are paid very little - if at all ${ }^{76}$ - to provide low-level labor for a practicing lawyer. Some lawyers face challenges in finding an apprenticeship opportunity of any kind. ${ }^{77}$

Of course, the existence of problems with the apprenticeship does not necessarily mean that clinics are the answer: the most straightforward approach would probably be to reform the apprenticeship program. This type of reform could work if there were a systematic program for training, monitoring and accreditation of mentors, with some control over the content being taught and the methods for teaching. In other words, to work, a reformed apprenticeship experience would need to look a lot like a law school clinic, but with teaching responsibilities spread throughout the practicing bar. In the end, the training and commitment required to reform the apprenticeship would almost certainly demand greater effort and resources than would be required to simply introduce clinics into law schools. It is the law schools that are best equipped to sequence teaching of doctrine and practice, to integrate the teaching and learning of students in a controlled environment. ${ }^{78}$

The existing apprenticeship requirement is not a good reason to reject law clinics - to the contrary, law clinics are an ideal vehicle to address the

73. There are approximately 7000 members of the bar in Taiwan.

74. Even assuming excellent supervision and teaching, no lawyer is allowed to have more than three interns at any given time, so the best teachers will still be extremely limited in their availability. Regulations Governing Pre-Service Training for Attorneys $\$ 10$.

75. Bücker \& Woodruff, supra note 2, at 610 .

76. Anecdotal evidence suggests that the influx of lawyers means serious competition for internship slots, and many young lawyers are forced to work for free. In other words, the young lawyer is self-financing the mandatory training. This might serve as a barrier to entering the profession for students who are not able to volunteer for five months with no source of income. Perhaps not all of the problem lies with experienced practitioners. New lawyers may also play a role in this: anecdotal reports suggest that students seek out supervising lawyers who will provide a less intense internship experience - they are not seeking out the kinds of mentors who can provide them with excellent training; instead, they are simply trying to fulfill this requirement with the smallest amount of effort possible.

77. Chen, supra note 58 , at 6.

78. See id. at 10. 
shortcomings in the apprenticeship. In light of modern clinical methods and the potential of practical education taught by clinic professors who are trained in pedagogy, it no longer makes sense to leave the bridging of theory and practice in the hands of a bar that is not able to handle the influx of new attorneys and not trained in teaching them to engage in reflective practice. The apprenticeship has worked in the past-in a different set of professional circumstances - and it could still be a valuable way to introduce young lawyers to local practice. But it can no longer be relied on as the sole source of practical training for lawyers. Clinical education can help address the weaknesses in the apprenticeship model while serving as a tool to prepare Taiwanese lawyers for practice. ${ }^{79}$

\section{B. Concerns about Student Practice}

Another enduring and ubiquitous source of objection to clinical work is concern about student practice - specifically students' ability to work with real clients, the legality of student practice, and the quality of student work.

\section{Lack of Student Maturity and Ability}

One concern about clinical education in undergraduate legal education generally is whether students who are barely out of high school are ready for the demands of legal representation of real clients. A common notion is that they are "too young to think for themselves and need first to accumulate a corpus of knowledge" ${ }^{\$ 0}$ before they are ready to actually practice with clients or "to take full advantage of professional training." " In some cases, there is an abiding notion that students are not capable of doing more than observing. ${ }^{82}$

Critics have directed the same sort of accusations of immaturity at

79. One innovative proposal from South Africa is to let participation in a law clinic count as a substitute for the practical internship required for admission to the bar. Wortham, supra note 18, at 663. The primary goal of the South African proposal was to address obstacles that were limiting access to the profession for some young lawyers. Such an arrangement might be beneficial in Taiwan, given the challenges students can face in finding internships. In addition, it would relieve pressure on the practicing bar.

80. Alain Lempereur, Negotiation and Mediation in France: the Challenge of Skill-based Learning and Interdisciplinary Research in Legal Education, 3 HARV. NEGOT. L. REV. 151, 164 (1998).

81. Margaret Barry, Clinical Legal Education in the Law University: Goals and Challenges, 2007 INT'L. J. CLINICAL L. EDUC. 27, 30 (2007).

82. Joy et al., supra note 67 , at 454. (Describing the Japanese belief that students can only observe, not practice law). In a subsequent article, Professor Joy and his co-authors suggest that this belief has led to a reliance on simulations as opposed to law clinics in Japan. Peter Joy et al., Japan's New Clinical Programs: A Study of Light and Shadow, in The Global Clinical Movement 115 (Frank S. Bloch ed., 2010). 
Taiwanese law students generally - they have been compared to "flowers or plants raised and nurtured in the greenhouse" 83 whose "limited social and work experiences" have hindered their ability to understand complicated legal issues. ${ }^{84}$ Criticisms of this nature resonate especially powerfully with respect to clinical programs, where real clients are involved and the individual stakes are often quite high.

Even if these claims are true, however, ${ }^{85}$ it is not a compelling argument against incorporating clinical education into undergraduate legal education. Law as an undergraduate degree is the norm throughout the world-the American post-graduate model is a notable exception. And clinical programs are thriving around the world in these same undergraduate systems.

It is conceivable that clinical education's global success may simply be due to prodigious supervisory efforts. However, the more likely reason is that the inability of undergraduate students to learn to be lawyers is simply overstated. The "maturity gap" between advanced undergraduate students and graduate law students is not actually very large. Law students in the U.S.-who are graduate students-are typically allowed to participate in clinics by their second year of law school (some schools even allow students to enroll in clinics in the second semester of the first year). This means students are around 23 when they are able to participate in law clinics-not a significant difference from law students in Taiwan who are 21 or 22 during their final year of law school. Any concerns about the maturity level of undergraduate students might be addressed by limiting student participation to upper-year students.

Finally, concerns rooted in law as an undergraduate degree are better understood as an argument for introducing clinical education. A student with an undergraduate law degree who has passed the bar at 22 will be a practicing lawyer in very short order (after completing the apprenticeship requirement). This lawyer is not likely to independently develop significant maturity or ability to learn from experience in the few short months between graduation and full qualification for practice. Experience in a law clinic, however, can help ameliorate this problem. By controlling and supervising young lawyers' first experiences with client representation, a clinical experience can help identify and address any deficiencies in maturity or ability to handle the challenges of client representation while training these younger lawyers to develop the skills of reflection and learning from

83. Lo, supra note 60 , at 43.

84. Id. at 53 .

85. I am personally quite skeptical of the notion that undergraduate students are as a rule too immature for practical and clinical legal education. After several years of teaching in a US clinic and a full year teaching experiential courses to Taiwanese law students, I cannot detect a meaningful difference in the relative maturity and ability to learn from experience between these two sets of students. 
experience. To the degree that problems with maturity are an actual problem, clinics present an ideal means to address the issue.

\section{Legal Concerns about Student Practice}

When people hear about clinical education for the first time, almost invariably the first question they have is whether it is legal for students to practice law. ${ }^{86}$ Most jurisdictions place limitations on who can practice law and under what circumstances. To avoid legal problems with a clinic, any student representation of clients must studiously avoid putting students in a situation that would result in them engaging in the unauthorized practice of law. ${ }^{87}$ This does not necessarily mean that clinical education cannot succeed without an express authorization of student practice - clinic design can adapt to virtually any situation-rather that this is a concern for clinic design and operation. ${ }^{88}$

In some jurisdictions, the importance of student practice has been recognized and expressly allowed by law-for example, this is the case in the U.S., where virtually every state and federal jurisdiction affirmatively permits students to practice. ${ }^{89}$ Chile $^{90}$ and the Philippines ${ }^{91}$ also expressly allow student practice.

These laws usually show careful tailoring of the student practice rule to

86. Professor Leah Wortham interprets as a form of American-clinical-model bias that sometimes almost the first words from American clinicians inquiring about clinics abroad are: "Is there a student practice rule?" Wortham, supra note 18, at 674. While Professor Wortham may be correct about the motivations and assumptions of some clinicians, in my experience this issue is a primary concern about clinical education everywhere. It does not mean that there is no way to create a clinic in the absence of a student practice order, or that the questioner has any particular biases, just a general concern that reflects the popular perception that lawyers possess an absolute monopoly over all law-related tasks.

87. Although these laws are routinely under-enforced, it is of course still preferable to have law clinics scrupulously abide by the laws on practice.

88. See however, Joy et al., supra note 82, at 114 (arguing that the lack of a student practice order is a significant hindrance to clinical development in Japan).

89. For a complete listing, see Student Practice Rules - Clinical Research Guide, http:/www.ll.georgetown.edu/guides/StudentPractice.cfm (last visited Sep. 10, 2012). The development of these rules was the product of the combined interests of advocates for expanding legal services and law schools wanting to make clinical experiences more meaningful. Thomas F. Geraghty et al., Access to Justice: Challenges, Models and the Participation of Non-Lawyers in Justice Delivery, in ACCESS TO JUSTICE IN AFRICA AND BEYOND: MAKING THE RULE OF LAW A REALITY 53, 73 (2007).

90. In Chile, upper-level law students can perform all of the functions of lawyers. Wilson, supra note 20 , at $567-68$.

91. Rules of the Court of the Philippines, § 138-A (1997) (Phil). "A law student who has successfully completed his [sic] 3rd year of the regular four-year prescribed law curriculum and is enrolled in a recognized law school's clinical legal education program approved by the Supreme Court, may appear without compensation in any civil, criminal or administrative case before any trial court, tribunal, board or officer, to represent indigent clients accepted by the legal clinic of the law school." 
reflect local needs, priorities and concerns. For example, student practice laws often require students to have completed a certain number of law school credits. ${ }^{92}$ Some require a student to be working as part of a law school clinic. ${ }^{93}$ Some rules limit student practice to certain practice areas - the U.S. $3^{\text {rd }}$ Circuit restricts student practice to criminal matters, apparently because it has identified that as the area of greatest need. Some rules limit student representation to indigent clients. ${ }^{94}$ Student practice rules can be drafted to meet a wide variety of goals and concerns of the legal system.

In most jurisdictions, however, there is no affirmative rule permitting student practice. Note that this does not mean it is prohibited-usually it simply means that clinics must be aware of the law and make sure to operate within its parameters, whether they are affirmative or prohibitive. It is useful to keep in mind what student practice in a clinic typically looks like: the client is a client of the clinic, not the student. All work is done under close supervision by an experienced attorney and as part of a law school course. It is not a matter of the students starting their own law firm and setting out to practice law. Keeping in mind what student practice means in this context, it should usually be possible to design a clinic that complies with local laws and ethical responsibilities while providing quality representation and a quality educational experience.

In Taiwan, there is currently no affirmative permission for student practice. However, there is also no prohibition on student practice and the law actually contains significant latitude in terms of who can represent others and in what types of matters, as well as a very narrow set of practices that are prohibited. This suggests that, with careful design and planning, it should be possible to create a clinical experience that complies with current law in Taiwan.

In litigation matters, Taiwanese law actually contemplates courtroom representation in civil and criminal defense cases by non-lawyers, as long as the non-lawyer receives judicial permission. ${ }^{95}$ Theoretically, it would be possible for students to represent clients in court. Of course, student representation would mean a reliance on the good graces of judges to permit that representation, so it is not ideal. In courtroom settings, clinical professors or students would be put in the position of having to ask for

92. $I d$; $\mathrm{N}$. Y. JuD Law $\$ 478$. (requiring at least 2 semesters).

93. Rules of the Supreme Court of the State of Hawaii $§ 7.1(a)(2012)$.

94. Mass. S.J.C. Rule 3:03(1)(a)-(b) (2010) ; KY. Sup. Ct. Rule 2.540 (2012).

95. "Only an attorney may act as an advocate, except where the presiding judge permits a person who is not an attorney to act as an advocate." Minshih Susung Fa [Taiwan Code of Civil Procedure] $\S 68(2009)$. "A defense attorney shall be a lawyer, provided that if permission is obtained from the presiding judge at trial, a person who is not a lawyer may be retained as a defense attorney." Chunghua Minkuo Hsingshih Susung Fa [Taiwan Code of Criminal Procedure Act] \& 29 (2012). 
permission for students to act as advocates for clinic clients. ${ }^{96}$ However, it is clear that the Taiwanese legal system is at least nominally open to having non-lawyers representing others in court.

Taiwan also does not have a definitive prohibition relating to law practice generally. There is no clear delineation of what is or is not considered the practice of law, ${ }^{97}$ and there is no express prohibition of the practice of law by non-attorneys-the Attorney Registration Act affirmatively states that admitted attorneys may "engage in the practice of law" 98 but (aside from a narrow list including certain types of criminals and disbarred lawyers $)^{99}$ does not generally prohibit anyone else from practicing law, with the narrow exception of criminalizing litigation for profit by non-lawyers. $^{100}$

The current lack of a definitive rule about student practice, while not optimal, does mean that within the parameters of current Taiwanese law, there is space for students in a law clinic to do legal work. In the courtroom, students could even be allowed to represent clients as far as arguing before judges. ${ }^{101}$ Outside the courtroom, there seems to be no limit to the work that students might do. ${ }^{102}$ And most of what attorneys do takes place outside of court: interviewing clients, client counseling, advising clients, drafting documents (litigation or transactional), legal research, preparing for court,

96. See Joy et al., supra note 67, at 438 (describing a similar problem faced by clinic professors in Japan). An arrangement like this has been regularized by clinicians in Australia. See, e.g., Susan Campbell \& Alan Ray, Specialist Clinical Legal Education: An Australian Model, 3 INT'L. J. CLINICAL L. EDUC. 67, 71 (2003) (describing clinical programs at Monash University, Melbourne, in which courts have allowed students to appear in a limited set of tribunals). Ideally, increased familiarity with student practitioners and high-quality work of clinic students would lead to greater approval from courts for student practice. It is probably a safer course, however, to try to change the law to affirmatively provide for student practice.

97. Attorney Regulation Act $\$ 20$ (2010). The act defines the "practice of law" to include (but not limiting it to): "handling trademarks, patents, commercial and industrial registrations, land registrations and other legally permissible law related business." (Attorney Regulation Act $\$ 20$ ) There is no discussion of what a lawyer does, so it is not clear whether it includes counseling, giving legal opinions, filing documents, drafting documents, negotiating or other lawyering activities. Although it may not matter, in light of the lack of a prohibition on non-attorney practice, more clarity would nevertheless be helpful.

98. Attorney Regulation Act $\$ 20(2010)$.

99. Attorney Regulation Act $\$ 4$ (2010).

100. The Attorney Regulation Act provides that "one who practices for profit, litigation without being licensed as an attorney" can face imprisonment and fines. Attorney Regulation Act $\$ 48$ (2009).

101. Given the current state of the law, however, clinic professors would need to be prepared for strategic requests from opposing counsel to deny or withdraw judicial permission, and professors would need to be prepared for the possibility that they may be required to handle any courtroom elements of representation.

102. A certain degree of representation by law students appears to be taking place already, in the Legal Aid Society setting (see supra note 58). Students who are lightly supervised by law faculty members meet individuals with legal problems and often provide some degree of legal counsel. This has been going on openly for about 30 years, and to my knowledge there has never been an objection on the grounds of unauthorized practice of law. 
and negotiating, among many other types of work. For students, these are meaningful student experiences - it is a mistake to think that a potential limitation on students' ability to speak in court to a judge on a client's behalf devalues the lawyering experience in a meaningful way. ${ }^{103}$ In fact, many clinics focus on transactional matters, which can give a robust lawyering and educational experience to students while generally permitting the clinic to avoid concern about student appearances in court.

Although the current law clearly leaves room for student practice in Taiwan, it is not ideal. It would benefit the bar and legal education for the legislature to craft thoughtful guidelines that clarify the boundaries of student practice. This could address any potential concerns about student practice by, for example, limiting student practice to upper-level students, or requiring the student to be under the supervision of a clinical professor. Restricting representation to indigent clients as a way to address unmet legal needs and simultaneously assuage concerns from the bar about stealing clients would also be an option.

For the present, however, it should be a relatively straightforward matter for students to work in a law clinic under the close supervision of licensed attorneys. A well-designed law clinic should be able to operate within the bounds of existing law while still providing a meaningful opportunity for students to provide real representation to real clients.

\section{Bar Resistance: Stealing Clients and Substandard Practice}

In some places, the bar has proven resistant to student practice for various reasons. ${ }^{104}$ In the U.S., for example, the bar was initially concerned that clinics "would divert business away from private practitioners." 105 It was not long, however, before this concern "dissipated as far as law school clinics are concerned because it was demonstrated that law school clinics posed no threat to the economic interests of the practicing bar."

103. However, the inability to litigate may be a problem for the clients. Clients are best served when they and their lawyers can credibly threaten and commence litigation if necessary.

104. This is not limited to the U.S. See Wilson, supra note 19, at 430 (asserting that "The bar often resists changes that permit even limited student practice"); Wilson, supra note 49 , at 834 (describing resistance from the bar in Western Europe); Uphoff, supra note 59, at 315 (describing resistance from the bar in Romania).

105. Geraghty et al., supra note 89 , at 73 .

106. Id. As early as 1969 , one survey indicated that $88 \%$ of practicing lawyers surveyed were in favor of student practice (Grossman, supra note 12, at n.94). It has also been claimed that clinics might actually increase business for the local bar by stimulating demand for legal services. Richard Lewis, Clinical Education Revisited 16 (Jan. 20, 2012), http://ssm.com/abstract=1988997. I have heard similar sentiments from lawyers at Taiwan's Legal Aid Foundation, who claimed that the local bar was happy to have them providing low-cost representation to low-income individuals because it was actually leading to increased paid work. Apparently the availability of low-cost legal services has created a general societal "habit" of consulting lawyers on matters that in the past might have been 
The reason is simple: clinic clients are almost guaranteed to be those who cannot find other counsel - the slow-motion, student-driven approach of clinical methodology means that any client who can afford private counsel is almost certain to do so.

Another source of concern from the bar has to do with the quality of representation in student clinics. That concern is obvious in the various requirements for supervision and limitations on practice areas. In the U.S., quality control concerns quickly evaporated because it became apparent that "the quality of services provided by law school legal clinics more than met professional standards."107 Low caseloads and intense supervision combine to keep quality of representation uniformly high in clinics. There has only been one reported case of a clinic being sued for malpractice, ${ }^{108}$ and the case was dismissed. ${ }^{109}$

Familiarity with clinics also seems to assuage these concerns. Perhaps the most meaningful thing to be said about the relationship of the bar to student practice in law clinics is that in the U.S. and Chile, for example, which have both had ample time to understand and assess the virtues of student practice, there is virtually no remaining resistance to student practice. $^{110}$

\section{Challenges with Teaching in Clinics}

\section{Teaching Methods}

Clinical education is radically different from the traditional lecture-based education that is common around the world. This can lead to suspicion or at least discomfort, and concerns about whether students or teachers will be able to adjust to this method. ${ }^{111}$ In Taiwan, the traditional

handled privately.

107. Geraghty et al., supra note 89 , at 73 . Indeed, in some cases the complaint from the bar is that legal clinic representation gives clients an unfair advantage. See Grossman, supra note 12, at 183. (reporting accusations of clinic students abusing their ability to devote time to litigation matters).

108. Juengain v. Johnson, 571 So.2d 167 (La. App. 1990).

109. Id. The opinion does not describe the claims against the clinic and its director when dismissing them. This is not to say that law students never make mistakes, of course. It may be the case that malpractice is not an issue because the nature of typical clinic cases and clients-small monetary amounts and poor, unsophisticated clients- do not lead to malpractice claims. Out of an abundance of caution, clinical programs also tend to carry spectacular malpractice insurance.

110. There is occasionally some politically-motivated objection to student practice usually based in general opposition to law clinics-when a law clinic that is "too successful" in representing underserved communities. See Peter Joy, Political Interference in Clinical Programs: Lessons from the U.S. Experience, 8 InT'L J. CLINICAL LEGAL EdUC. 83 (2005).

111. In one extreme case, a clinician was told that "clinical education methodologies are unorthodox and untested and therefore not worthy of the [very prestigious] University's high standards." Haider Ala Hamoudi, Toward a Rule of Law Society in Iraq: Introducing Clinical Legal Education into Iraqi Law Schools, 23 BERKELEY J. INT'L L. 112, 116-17 (2005). 
law school teaching method has been a teacher standing in front of a large class and lecturing, with "little classroom interaction between professors and students-neither asks questions-and students rarely challenge their professors in class." $" 12$ The reasons for this are numerous-perhaps the most obvious one is efficiency. With a large classroom, highly interactive discussions may just not be possible. Given the pressures of bar preparation and the need to give students a great deal of information in the most efficient way possible, lecture format is an obvious choice. However, in an environment such as this, students do not need to be prepared, and teachers may not be interested in teaching to a student body that is not invested in learning. Students may prefer this type of teaching as well-it is certainly less demanding to be in a classroom in which they are simply told what the law is and how to process that information. Finally, these are the methods that have worked for generations of law students-including the professor standing at the head of the class-and sometimes that leads to resistance to change. ${ }^{113}$

Of course, experiential education requires a very different sort of interaction and set of expectations between student and instructor. The contrast between a lecture model and an interactive feedback-intensive learning model is significant. In an interactive classroom, students are taught to learn from their own experiences. Teaching prizes autonomous student discovery and reflection, and requires the professor to be flexible and patient. A significant focus of the type of interactive pedagogy commonly used in clinical education is "student learning rather than faculty teaching, which sometimes contributes to resistance from more traditional faculty." 114 In addition, it has been suggested that professors accustomed to non-interactive lectures would not be able to make the transition. ${ }^{115}$

With respect to the distinctions between teaching in civil law and common law jurisdictions, it is true that there seems to be a divide, at least

112. Lo, supra note 60 , at 62 .

113. Joy et al., supra note 67 , at 454 . (describing Japanese educators' resistance to change in teaching methodologies).

114. Wilson, supra note 19 , at 428.

115. Professor Alain Lempereur describes a (perhaps slightly tongue-in-cheek) hypothetical skills course in France: "One could easily imagine what a course dedicated to [Alternative Dispute Resolution] would look like in this non-interactive context. First, a professor would look for the articles of the given code, which may allow or disallow use of ADR. This positivistic observation would be complemented with additional court decisions illustrating how the legislation should be applied. The questions raised in class would be about the formalistic guarantees of procedures that should accompany alternative modes of dispute resolution. Discussion would focus on what might make the procedure void and on possible recourses through litigation. At no time would there be discussion as to what would produce a good settlement or what would make negotiation, mediation, and arbitration a success from the parties' viewpoint. What this makes clear is that changes in the general teaching format used in law schools are necessary before ADR courses can be effectively instituted in the classroom." Lempereur, supra note 80, at 164-65. 
traditionally, between the ways that law is taught in each. Generally speaking, teaching in civil law jurisdictions tends to be lecture-based, while instruction in common law jurisdictions tends to be more interactive (often in the form of what is called the Socratic method). ${ }^{116}$ But this traditional difference does not seem to be an inherent distinction between civil and common law systems-the existence and success of interactive teaching methods in civil law jurisdictions around the world makes it clear that the distinction is not closely connected to the underlying nature of the system. ${ }^{117}$

With respect to Taiwan, concerns about the appropriateness of interactive, reflective and feedback-intensive teaching are clearly unfounded. Law professors and students throughout Taiwan are already participating in seminars, small feedback-intensive courses and even simulation courses with great success. Whatever the traditional teaching approach might have looked like, a non-lecture approach to teaching has already been established in Taiwan. This type of teaching is gaining ground as more teachers who are educated around the world bring a variety of teaching practices to Taiwan, ${ }^{118}$ including experiential and seminar courses.

Concerns about student acceptance ${ }^{119}$ of practical education also seem unfounded. When they are given the option, students embrace practical education. ${ }^{120}$ The simulation courses I have been teaching at National Taiwan University - some of the first of their kind in Taiwan-officially limited to 18 students, have had wait lists of 50 to 70 students each semester. ${ }^{121}$

Lecture-based teaching may still be a common model in Taiwan, but it is hardly a monolithic approach to legal education. Teachers and students have shown a willingness to embrace other teaching methods and to learn how to employ them effectively.

116. See Genty, supra note 55, at 139-40.

117. See id. at 147 (recounting the success of interactive teaching in civil law countries such as Poland, Czech Republic and the Netherlands).

118. Lo, supra note 60 , at 42.

119. One often-raised concern about clinical education in Taiwan is that there might not be student demand due to the intense pressures law students face to prepare for and pass the bar examination. Given the existence and popularity of several experiential courses in Taiwan's law schools, this seems to be an unfounded concern. (But see Joy et al., supra note 82, at 113) (arguing that pressure to pass the bar is hindering the clinical movement in Japan). At the same time, it has been suggested that bar passage rates are kept low because legal education is so bad at preparing law students to practice, creating a self-reinforcing shortage of practical training and bar passers. Chen, supra note 58 , at 10 .

120. Professor Hamoudi recounts how, despite predictions from Iraqi professors that students would not be interested in practical legal education, more than $2 / 3$ of the law school signed up for an experience-based educational program. Hamoudi, supra note 111, at 112 .

121. Student reviews of the course have been uniformly positive and enthusiastic about this type of educational experience. 


\section{Who will Teach Law Clinics?}

Another source of concern is the challenge of finding qualified and capable teachers. In a place like Taiwan, with no history of clinical education, there is no obvious existing pool of teachers. Although many law professors have practical experience, the historical focus on doctrine and analysis has not prepared existing law faculties to design and implement a law clinic. But instructors who combine expertise in practice with the ability to teach and supervise student practice are crucial for clinical education to achieve its potential.

This is not a unique problem. It has been a common issue when establishing clinics around the world. In the U.S., where the ideology of the case-based method meant that lawyers with practice experience were "shunned by law schools,"122 the first wave of clinical professors was drawn chiefly from the ranks of practicing legal aid lawyers with extensive practice experience. ${ }^{123}$ Given funding and support from law schools, they were able to develop efficient methods for clinical practice and teaching, which soon developed into an extensive body of experience and scholarship. Similar experiences are the standard around the world. However, the collective experience of these clinicians has led to a general easing of the challenge of entering the field. Today, there is a staggering array of resources for new clinicians based on the accumulated scholarship and reflection of generations of clinicians around the world, including clinic-related journals, ${ }^{124}$ textbooks, ${ }^{125}$ clinical conferences, and global and regional organizations of clinical teachers.

Late adopters of clinical education, like late adopters of technology, have a certain undeniable advantage. They can learn from the experiences of others and speed up their own progress in becoming effective clinic

122. Grossman, supra note 12 , at 182.

123. Wortham, supra note 18, at 668-69. For a fascinating look at those early days, see Michael Meltsner \& Philip G. Schrag, Report from a CLEPR Colony, 76 COLUM. L. REV. 581 (1976).

124. For example, see Clinical Law Review (U.S.); Journal of Law \& Education (U.S.); Journal of Legal Education (U.S.); The Journal of Legal Studies Education (U.S.); Brigham Young University Education and Law Journal (U.S.); Thomas M. Cooley Journal of Practical and Clinical Law (U.S.); Education \& Law Journal (Canada); Education and the Law (U.K.); International Journal of Clinical Legal Education (U.K.); Journal of Commonwealth Law and Legal Education (U.K.). One of the most comprehensive sources of information on legal clinics in the United States is the research conducted by the Center for the Study of Applied Legal Education at the law school at the University of Michigan. See Santacroce \& Kuehn, supra note 47.

125. Professor Wilson believes that "the single most significant impediment to the development of an effective classroom component - indeed to the integrity of the teaching enterprise of clinical education - is a coherent body of material on theories of law practice, as well as skills training materials for students." Wilson, supra note 20, at 515. At least one of these-ESSENTIAL LAWYERING SKILLS, by Stefan Krieger and Richard Neumann-is available in Traditional Chinese characters. I have been using this book in my courses this year. 
professors. New clinicians in Taiwan could select from the most cutting-edge developments in clinical education around the world and adapt them to local Taiwanese needs and realities.

There is another, more practical, concern for clinical professors in Taiwan: law professors at public law schools in Taiwan are not allowed to practice law. ${ }^{126}$ Without a change to the law ${ }^{127}$ or special dispensation from the Ministry of Education, clinic professors at most Taiwanese law schools would have to come from outside the faculty. This seems like a small problem initially: certainly Taiwan has a long history of hiring practicing lawyers as adjunct professors in its law schools. This would be a good way to get clinical programs started, but might lead to problems with sustainability and teacher retention if it were unaddressed in the future.

The enforced separation also creates a situation where law school is less and less connected to the realities of practice and the important questions of what competencies lawyers need and evolving practice norms. Hiring adjunct professors is a short-term solution, but the larger issue of the separation of practicing lawyers and law schools should be addressed.

\section{Resource Concerns}

A constant source of concern with clinics is the cost of clinical education. When clinics present a perceived threat to the resources allocated elsewhere in the law school, there is usually resistance to clinics. Relative to more traditional classes that can have dozens, if not hundreds, of students and a single teacher, clinics are perceived as expensive-the intense supervision required in a clinic means that teacher-student ratios are extremely low, especially in comparison. But this is an inappropriate comparison-a more apt comparison is to small seminar courses, which abound in Taiwanese law schools.

Law schools have learned to appreciate the educational value and student engagement of small courses, despite the relatively higher costs. Clinics, with their potential for a broad range of student learning,

126. This is because they are considered government employees, who may not be attorneys. See Attorney Regulation Act $\$ 31$. However, according to anecdotal reports, the Ministry of Education has recently given its approval for law professors at some private law schools to continue to practice law. (This makes sense since they are private employees, it seems that there would be no rationale other than custom for applying the prohibition to these professors.) It is not entirely clear what the rationale for this prohibition might be. Laws and regulations limiting legal practice by law faculty exist in many jurisdictions, and they are not necessarily unreasonable - they can serve a useful purpose in making sure that law professors are more focused on teaching than working for clients. However, because clinic professors are using the practice of law as a tool for teaching, it makes sense to create exceptions for clinical teaching, regardless of any underlying rationale for limiting law practice by professors.

127. Japan changed its law in 2003 to allow law professors to be practice law. Joy et al., supra note 67 , at 430 . 
engagement and development, as well as their potential benefit in public relations and student recruiting, should not be discounted simply because they are less efficient than large lecture classes. Cost is not-and should not be-the most important factor in curriculum design, and it should not drive decisions about clinics. ${ }^{128}$

It is true, however, that clinics require resources, ${ }^{129}$ which can draw opposition from faculty. But clinics around the world have shown surprising flexibility and creativity in dealing with the costs of operating clinics in environments of scarce resources. Despite some concerns that clinics were too resource-intensive to succeed outside of wealthy, developed nations, the explosive growth of clinics has shown that clinical education is not beyond the reach of any country or any legal education system that is able to address the problem creatively. ${ }^{130}$

First, there may be outside resources available for starting clinics. ${ }^{131}$ Second, creative arrangements can reduce financial costs for law schools without reducing quality of education. ${ }^{132}$ One cost-reducing option that is common around the world is the so-called "hybrid" clinic. A hybrid clinic is typically one in which the law school partners with an existing law firm-usually a legal services agency-to take cases that are the responsibility of the law students and the clinic when students are there, but that will return to the agency when school is not in session. In this case, the agency controls intake of clients and usually has some input on case-related decisions. The costs of the clinic are reduced by limiting the need for support staff, summer and holiday coverage, publicity and other costs. ${ }^{133}$ As a trade-off, however, law schools sacrifice control over the educational experience of their students.

There are also other possible solutions. In Japan, for example, one innovative solution was the development of collaboration between the Tokyo Bar Association and four local law schools to avoid duplicating the costs of running separate clinics and instead share costs to help provide cost-effective

128. As Professors Barry, Joy and Dubin point out, if cost were the only factor, then a much higher number of courses would be taught by adjunct professors. Barry et al., supra note 14, at 25-26.

129. One response to this has been to rely heavily on simulations. I think this is a mistake: the most significant benefits of clinical education simply cannot be replicated by simulations. See supra notes $7-8$ and accompanying text.

130. Wilson, supra note 19 , at 430 .

131. Professor Wilson identifies five important sources of international funding for clinics, for example. $I d$. at 421 .

132. Although it is an understandable temptation to increase student-faculty ratios or to use adjunct or other lower-status professors to teach clinics, these short-sighted measures will lead to a lower-quality educational experience, which may ultimately threaten the sustainability of clinical education.

133. This type of arrangement may also have some appeal as a way to insulate the law school from controversy resulting from casework or client selection. Grossman, supra note 12, at 175. See Joy, supra note 110 , for a discussion of political interference with clinical education. 
clinical opportunities for their students. ${ }^{134}$ Such an arrangement might work in Taiwan, where there are numerous law schools in a relatively small geographical area. Given the proliferation of clinics in Taiwan's region, cross-border collaborations might even be feasible.

Another proposal is to charge separate student fees for clinical work. At least one program has actually done this-the Samara State University (Russia) school of law arranged a separate tuition fee for its clinical program, with students receiving a special certificate of clinical training. ${ }^{135}$ Another suggestion has been to charge the bar-in the form of increased registration fees that are then directed toward clinical education. ${ }^{136}$ Other ideas that might reduce costs are short-term clinics, ${ }^{137}$ and limiting practice to certain areas of law with limited resource requirements. ${ }^{138}$

Finally, it is important to recognize the value that law schools have undeniably placed on clinics as tools to produce graduates who are prepared to excel in legal practice, to provide good publicity and a solid community reputation to law schools, to recruit top students, and to establish and maintain community relationships. Notwithstanding the resources required, the continued popularity of clinical legal education globally suggests that law schools agree that it is worth the cost.

\section{E. Clinics in a Civil Law System}

Because clinical education is so closely identified with American legal education, it is also closely identified with the American common law legal system. As a result, there may be concerns about the feasibility of clinics in civil law systems. It is certainly true that there are differences between civil and common law systems that may be relevant for clinical education. ${ }^{139}$

134. Joy et al., supra note 67 , at $445-47$

135. Wortham, supra note 18 , at 628 . A proposal like this might be well-received by students who are already effectively paying for their practical training by working for five months for free during their internships.

136. David Barnhizer, Of Rat Time and Terminators, 45 J. LEGAL EDUC. 49, 57 (1995). This proposal might meet with support from the bar if it were framed as a source of relief from existing apprenticeship responsibilities of experienced lawyers.

137. See Joy et al., supra note 67 , at $450-51$ (describing a clinic that lasts for one week at a time, in which students travel for short periods to remote areas of Japan that lack lawyers); Krieger \& Martinez, supra note 8 (describing a one-day clinical experience involving multiple brief opportunities to represent clients who had been denied the opportunity to vote in New York).

138. For a fuller discussion of the benefits and operation of a small-case clinic, see Ian Weinstein, Teaching Reflective Lawyering in A Small Case Litigation Clinic: A Love Letter to My Clinic, 13 CLINICAL. L. REV. 573 (2006) (describing his students' work exclusively with bond hearings).

139. See Genty, supra note 55, at $149-52$ (concluding that at least five differences with implications for clinical education are: the relative importance of substance over process in civil law cultures; the importance to civil law systems of mastering doctrine (as opposed to creative interpretation); a different type of attorney-client relationship; the relative importance of authority figures in civil law cultures; and the relative unfamiliarity with the concept of cause lawyering in civil 
However, the mere presence of differences does not mean that clinics cannot work in civil law systems. Indeed, one of the longest-lasting and most successful clinical programs has been in Chile, which has a robust civil law tradition. ${ }^{140}$ There is obviously nothing inherent to civil law systems that would threaten the success of clinical education. Of course, that does not mean that there would be no difference in clinical education between systems - clinics in civil law systems, like law clinics in any jurisdiction, should be carefully designed to accommodate local norms and concerns. However, what differences do exist between common law and civil law systems can best be interpreted as factors that will affect the particular form that clinical education takes, rather than as barriers that would not allow for clinical education at all in civil law systems.

In the final analysis, none of the common objections to clinical education can withstand close scrutiny. This should not be surprising-clinical education is thriving around the world because it has demonstrated in place after place that it is adaptable to any legal education system.

\section{Moving Forward in TaiWan: How CAN Clinics Become a REality?}

I do not believe that any of the objections to clinical education that I have encountered, either general concerns or Taiwan-specific problems, are compelling. Clinical education can work in Taiwan or a similar system of civil law and undergraduate legal education. Reaching this conclusion, however, is simply the beginning for legal educators in Taiwan, who must decide whether Taiwan should experiment with clinical education.

There has historically been resistance to the introduction of clinics around the world. The reasons vary, but the most common is that clinical education, with its focus on giving students practical training, presents challenges to the identity and traditions of legal education and the professoriate. This may also be an issue in Taiwan, where many law professors hold the belief that "law school should be a place for academic study only." $" 141$ The primacy of scholarship is easy to see: professors are praised - and promoted - for their academic research and writing, not their teaching. There is not a lot of space for practical elements in this conception of the role of law school and the professoriate. Laws and traditions excluding professors from practice and practitioners from the law faculty have reinforced this divide.

The ambiguity of the relationship between law school and practice is a 
perennial element of global discussion of the role and value of clinics in law schools, exposing an identity crisis within the legal academy: is law school a technical education, like medicine, or a purely academic undertaking, like philosophy? Law clinics reliably confront this problem, facing resistance from faculty members who perceive a threat to tradition and to their place in the law school. ${ }^{142}$

This situation is certainly not specific to Taiwan: "[a]t the time of its introduction in the United States, clinical legal education fought the established academic community, which felt that clinical legal education risked converting the legal academy from preparation for a profession to preparation for a trade." ${ }^{143}$ This tension still remains to some degree, and similar sentiments are common worldwide. Opponents of clinics argue that the purpose of law school is to teach students to think and that training for practice is the responsibility of the bar. Proponents of clinics criticize legal education that lacks practical training by comparing it to learning to fly a plane by reading books about flight theory, or graduating from medical school without ever having seen a patient. ${ }^{144}$

The persistence of this debate has drawn needless lines between complementary elements of legal education, and this enduring false dichotomy obscures the real role of clinical education. As I have already argued, ${ }^{145}$ it is important for faculties to understand clinics not as in tension with doctrinal and theoretical learning but as an extension of the teaching that is already taking place in law schools. In addition to providing valuable preparation for practice, clinical education refines the ability to engage in legal analysis and enhances theoretical understanding of law, its values and its impact on real people and communities.

So, let us assume for the moment that I have convincingly argued that Taiwan, or a similarly-situated legal system, should start to incorporate law clinics into its legal education system. This conclusion offers no guidance about what a law clinic should look like and how a law school should answer the manifold questions that would arise with the decision to create it, such

142. Wilson, supra note 19, at 421. Frankly, concerns about clinical education redefining the law school or the nature of the faculty seem to be empirically unwarranted. The experience of clinical education globally makes it clear that there is no necessary reason that clinics cannot coexist with doctrinal analysis in the law school: even after decades of clinical education, there is no shortage of research scholars at the law schools that have clinical programs.

143. Wilson, supra note 49 , at 825 . Although clinics have established their place in American legal education, this tension persists to some degree. There is some ongoing tension within the legal education world-clinics "remain at the periphery of law school curricula." Barry et al., supra note 19, at 32. At most law schools, there is still no guarantee that every student will have the chance to participate in a clinic.

144. The highly influential Carnegie Report on American legal education goes further, arguing that focusing solely on legal theory and doctrine is not only lacking, but that it has a "corrosive effect" on professional development. See SULLIVAN ET AL., supra note 25, at 77.

145. See supra notes 10-13 and accompanying text. 
as: What area of law should the clinic target? Who will teach the clinic? Who should its clients be? What students will be eligible for the clinic? Where will the money come from? How will the success of clinical education be assessed? How many credits will students receive? What will its relationship be to the apprenticeship requirement? How will clinical education be integrated into the rest of the curriculum? And so on. ${ }^{146}$

Equally challenging is the host of questions that will be important for law faculties to resolve, such as the rewards, obligations, and requirements of law professors vis-à-vis the law clinic: can clinic professors be full-time faculty? Will clinic professors be eligible for tenure? What are the scholarship requirements for clinic professors? What kinds of scholarship would be acceptable? Are credit hours taught in a clinic equivalent to credit hours taught in a doctrinal class? What are the ethical issues that arise within the context of clinical legal education?

These questions are not easily answered-indeed, debate over these issues continues unabated in the U.S., where clinical education has a long and secure history, and around the world. As one international group of clinical professors has noted, "for these issues, clinical faculty in other countries might say, "Welcome to the world of clinical education." 147 These questions are common to clinical education globally. They will persist and new issues will appear, and all will require thoughtful responses and careful decisions.

The answers must come from Taiwanese law professors, lawyers and judges. It is not enough to simply copy what has been done in the U.S., ${ }^{148}$ or what is happening in China or Japan or anywhere else. Every version of clinical legal education relies on local resources, law, faculty interest and expertise, and other resources to shape it. ${ }^{149}$ The bridge between Taiwanese doctrinal teaching and practice will, of necessity, be a locally designed one,

146. For a more complete list of issues likely to arise, see Caplow, supra note 2, at 247-48. See also Philip Schrag, Constructing a Clinic, 3 CuINICAL L. Rev. 175 (1996).

147. Joy et al., supra note 67 , at 456.

148. Concerns about, and resistance to, American influence on clinical education do exist. Most clinicians worldwide are keen to avoid the missteps of the so-called Law \& Development Movement that was accused of "legal imperialism" in its efforts to export American legal education. Those concerns may be misplaced-clinical education has gone global to the point that it is not American or any other nationality. However, a recent effort to introduce clinics to Iraq met with strong hostility from Iraqi educators in part due to the perception that it was an effort to "Americanize" Iraqi education. See generally Hamoudi, supra note 111.

149. Examples of clinical diversity abound. In China, one school started a translation-based clinic that provides assistance to non-Mandarin speakers. Wortham, supra note 18, at 625. As mentioned in supra note 137, a Japanese law school created a mobile, periodical clinical program that travels to remote areas for one-week periods to provide legal assistance in areas that have no attorneys. Joy et al., supra note 67, at 450-51. Many programs incorporate "know your rights" or "street law" elements - providing education about rights and laws to client communities that are unsophisticated in these areas. 
crafted deliberately and consciously to reflect the needs of Taiwanese law students in the current legal environment.

Teachers, students, and clients around the world can testify to the benefits of clinical legal education. With some work and the will to make it happen, Taiwan can draw on a vast body of existing resources to create a successful program of clinical legal education relatively quickly, to the enduring benefit of its students and the legal profession. 


\section{REFERENCES}

ABA Section on Legal Education and Admission to the Bar. (2012). 2012-2013 Standards and Rules of Procedure for Approval of Law Schools (Standard 302(b)(1), Interpretation 302-305.)

Note. (2007) Adopting and Adapting: Clinical Legal Education and Access to Justice in China. Harvard Law Review, 120, 2134-55.

Amsterdam, A. (1984). Clinical Legal Education-A 21st century Perspective. Journal of Legal Education, 34, 612-18.

Lu_Shih Fa [Attorney Regulation Act]. art. 1, 4, 20, 31, 48.

Barnhizer, D. (1995). Of Rat Time and Terminators. Journal of Legal Education, 45, 49-60.

Barry, M. M. (2007, July) Clinical Legal Education in the Law University: Goals and Challenges. International Journal of Legal Education, 27-50.

Barry, M. M., Dubin, J. C., \& Joy, P. A.(2000). Clinical Education for this Millennium: The Third Wave. Clinical Law Review, 7, 1-76.

Bunn, C., Cavers, D. F., Falknor, J. F., Feezer, L. W., Llewellyn, K. \& Moreau, F. J. (1945). The Place of Skills in Legal Education. Columbia Law Review, 45, 345-91.

Burger, W. (1973). The Special Skills of Advocacy: Are Specialized Training and Certification of Advocates Essential to our System of Justice? Fordham Law Review, 42, 227-42.

Busharis, B. J., \& Rowe, S. E. (2000). The Gordian Knot: Uniting Skills and Substance in Employment Discrimination and Federal Courses. John Marshall Law Review, 33, 303-52.

Bücker, A, \& Woodruff, W. (2008). The Bologna Process and German Legal Education: Developing Professional Competence Through Clinical Experiences. German Law Journal, 9, 575-618.

Campbell, S., \& Ray, A. (2003). Specialist Clinical Legal Education: An Australian Model. International Journal of Legal Education, 3, 67-78.

Caplow, S. (2006). Clinical Legal Education in Hong Kong: A Time to Move Forward. Hong Kong Law Journal, 36, 229-58.

Chen, C. (2010). The Role of Practice in Legal Education: National Report for Taiwan, paper delivered at the $18^{\text {th }}$ International Congress on Comparative Law 10. (2012, January 12). Retrieved from http://ssrn.com/abstract $=1984374$

Chen, P. (2010, February 2). Practicing on Patients, Real and Otherwise. New York Times, pp. D6. 
David A. S. \& Robert R. K. (2010). Center for the Study of Applied Legal Education, The 2010-11 Survey of Applied Legal Education. (2012, May 16) Retrieved from http://www.csale.org/files/CSALE.Report. on.2010-11.Survey.5.16.12.Revised.pdf.

Dinerstein, R. (1992). Report of the Committee on the Future of the In-House Clinic. Journal of Legal Education, 42, 508-74.

DiFonzo, J., \& Schepard, A. (2011). Hofstra's Family Law with Skills Course: Implementing FLER (The Family Law Education Reform Project). Family Court Review, 49, 685-99.

Frank, J. (1933). Why not a Clinical Law School? University of Pennsylvania Law Review, 81, 907-23.

Frank, J. (1949). Courts on Trial. Princeton, NJ: Princeton University Press.

Genty, P. M. (2008). Overcoming Cultural Blindness in International Clinical Collaboration: The Divide between Civil and Common Law Cultures and Its Implications for Clinical Education. Clinical Law Review, 15, $131-56$.

Geraghty, T., Anderman, G., Hamsher, D., Hua, S., Majid, N., Sanders, D., \& Shaw, K. (2007). Access to Justice: Challenges, Models and the Participation of Non-Lawyers in Justice Delivery. In Penal Reform International (Ed.). Access to Justice in Africa and Beyond: Making the Rule of Law a Reality (pp. 53-86).Chicago, Ill: Northwestern University School of Law.

Grossman, G. S. (1974). Clinical Legal Education: History and Diagnosis. Journal of Legal Education, 26, 162-91.

Hamoudi, H. A. (2005). Toward a Rule of Law Society in Iraq: Introducing Clinical Legal Education into Iraqi Law Schools. Berkeley Journal of International Law, 23, 112-37.

Hawaii Rules of Supreme Court, Rule 7.1.a.

Hurst, J.W. (1950). Growth of American Law. Boston, MA: The Law book Exchange, Ltd.

Joy, P. A. (2005). Political Interference in Clinical Programs: Lessons from the U.S. Experience, International Journal of Clinical Legal Education, 8, 83-103.

Joy, P. A. (2010). Japan's New Clinical Programs: A Study of Light and Shadow. In Frank S. Bloch. (2011) The Global Clinical Movement (pp. 113-115). New York, NY: Oxford University Press.

Joy, P. A., Miyagawa, S., Suami, T., \& Weisselberg, C. D. (2006). Building Clinical Legal Education Programs in a Country without a Tradition of Graduate Professional Legal Education: Japan, Educational Reform as a 
Case Study. Clinical Law Review, 13, 417-58.

Johnstone, Q. (1951). Law School Clinics. Journal of Legal Education, 3, $535-54$.

Juengain v. Johnson. 571 So.2d 167 (La. App. Ct. 1990).

Kentucky Bar Association Rules of the Supreme Court of Kentucky. art. 2.540 .

Krieger, S. H., \& Martinez, S. A. (2010). A Tale of Election Day 2008:

Teaching Storytelling Through Repeated Experiences. Legal Writing:

Journal of the Legal Writing Institute, 16, 117-62.

Lempereur, A. (1998). Negotiation and Mediation in France: the Challenge of Skill-based learning and interdisciplinary Research in Legal Education. Harvard Negotiation Law Review, 3, 151-74.

Lewis, R. (2012). Clinical Education Revisited (2012, January 20). Retrieved from http://ssrn.com/abstract=1988997.

Lo, C.- f. (2006). Driving an Ox Cart to Catch Up with the Space Shuttle: The Need for and Prospects of Legal Education Reform in Taiwan. Wisconsin International Law Journal, 24, 41-84.

Maisel, P. (2008). The Roles of U.S. Law Faculty in Developing Countries: Striving for Effective Cross-Cultural Collaboration. Clinical Law Review, 14, 465-507.

Massachusetts Supreme Judicial Court Rule. art. 3:03(1)(a)-(b).

Meltsner, M., \& Schrag, P. G. (1976). Report from a CLEPR Colony. Columbia Law Review, 76, 581-632.

Milstein, E., Rivkin, D. H., Schrag, P., Scott, K., Wolf, R., \& Wortham, L. (1987). Symposium: Clinical Legal Education: Reflections on the Past Fifteen Years and Aspirations for the Future. Catholic University Law Review, 36, 337-40.

New York Judiciary Law. art. 478.

Quigley, W. P. (1995). Introduction to Clinical Teaching for the New Clinical Law Professor: A View from the First Floor. Akron Law Review, 28, 463-96.

Lu_shih Chihch'ien Hsünlien Kuitsê [Regulations Governing Pre-Service Training for Attorneys]. art. 5, 10, 11.

Rowe, W. V. (1917). Legal Clinics and Better Trained Lawyers-A Necessity. Illinois Law Review, 11, 591-618.

Rules of the Court of the Philippines. Rule 138-A.

Rules of the Supreme Court of the State of Hawaii § 7.1(a)(2012).

Schrag, P. G. (1996). Constructing a Clinic. Clinical Law Review, 3, 175-248. 
Sullivan, W. M., Colby, A., Wegner, J. W., Bond, L., \& Shulman, L.S. (2007). Educating Lawyers: Preparation for the Profession of Law. San Francisco, CA: Jossey-Bass, Wiley.

Standards for Approval of Law schools 2011-2012. § 302(b)(1) (2011).

Stevens, R. B. (1987). Law School: Legal Education in America from the 1850s to the 1980s. Chapel Hill, NC: University of North Carolina Press.

Minshih Susung Fa [Taiwan Code of Civil Procedure Act]. § 68. (2009) (Taiwan).

The Justice System Reform Council. (2001). Recommendations of the Justice System Reform Council - For a Justice System to Support Japan in the 21st Century, Chapter III, Part 2.2. (1)a-b.(2001, June 6). Retrieved from http://www.kantei.go.jp/foreign/judiciary/2001/0612report.html.

Chunghua Minkuo Hsingshih Susung Fa [The Code of Criminal Procedure Act]. § 29 (2012) (Taiwan).

Uphoff, R. J. (2000). Why In-House Live Client Clinics Won't Work in Romania: Confessions of a Clinician Educator. Clinical Law Review, 6 , 315-46.

Weinstein I. (2006). Teaching Reflective Lawyering in A Small Case Litigation Clinic: A Love Letter to My Clinic. Clinical Law Review, 13, 573-604.

Wilson, R. J. (2001-2). Three Law School Clinics in Chile, 1970-2000: Innovation, Resistance and Conformity in the Global South. Clinical Law Review, 8, 515-82.

Wilson, R. J. (2004). Training for Justice: the Global Reach of Clinical Education. Penn State International Law Review, 22, 421-31.

Wilson, R. J. (2009). Western Europe: Last Holdout in the Worldwide Acceptance of Clinical Legal Education. German Law Journal, 10, 823-46.

Wortham, L. (2006). Aiding Clinical Education Abroad: What Can Be Gained and the Learning Curve on How to Do So Effectively. Clinical Law Review, 12, 615-86. 


\section{臺灣的法律實皙課程 \\ 在大陸法系國家的大學部法律教育 是否可以成功推動?}

Serge A. Martinez

\section{摘 要}

在多數國家, 法律實習課程可謂法學教育重要之一環。但仍有許 多國家並未設有法律實習課程, 臺灣即一顯例。關於法律實習課程應 如何納入臺灣的法學教育系統, 此一議題值得臺灣的法學教育者關切 與深思。當論及法律實習課程, 普遍受到關注的議題包括: 大學部學 生能豿從事法律實習課程嗎? 能豿透過參與法律實習課程, 因而從中 獲得學習上利益嗎? 讓學生實際地參與法律實務, 是否有法律上之顧 虑? 由學生所參與之法律實務工作, 對於陳述之品質有何影響? 如何 使得學生所參與的法律實習工作，與既有的法律實務學徒制度相互配 合? 臺灣的法學院是否有足夠的經費支付學生的法律實習教育? 歸 根究柢, 上述之問題理應不構成向法學院的學生們介紹法律實習教育 的嚴重阻礙。臺灣的法學院應該在課堂向學生們介紹法律實習工作, 並給予機會使學生們獲益於法律實習教育。

關鍵詞：實習教育、法律實習、實用的法學教育、學生參與法律演 練、臺灣法學教育 